\title{
Severe physiological stress associated with the annual breeding emigration of Panulirus ornatus in the Torres Strait
}

\author{
Jasper T. Trendall ${ }^{1, *}$, James Prescott $^{2}$ \\ ${ }^{1}$ CSIRO Division of Fisheries, Bungalow PO, Cairns, Queensland 4870, Australia \\ ${ }^{2}$ Department of Fisheries and Marine Resources, PO Box 417, Konedobu, Papua New Guinea
}

\begin{abstract}
Juvenile lobsters Panulirus ornatus in the Torres Strait emigrate once a year from the Torres Strait to the Gulf of Papua, several hundred kilometres to the northeast. They mature and spawn during this emigration. After spawning the lobsters disappear. It has been suggested that the combined stress of reproduction and emigration results in mass mortality. To test this hypothesis, lobsters were collected at several stages of the emigration and their condition defined by the water content and composition of the digestive gland and abdominal muscle. A cage experiment, with 2 feeding regimes, was conducted to examine the likelihood of post-reproductive mortality. Compared to lobsters in the Torres Strait, before emigration takes place, lobsters that had completed the breeding emigration were in very poor condition. There were changes in the size and composition of both the digestive gland and abdominal muscle. Three stages of deterioration were recognised; in the final stage the digestive gland tissue was severely atrophied. The physiological characteristics identified in this study provide a quantitative basis for future work on the mortality rates of lobsters that have completed the emigration.
\end{abstract}

\section{INTRODUCTION}

Mass migrations associated with reproduction are common in spiny lobsters, but that of Panulirus ornatus in the Torres Strait, between Australia and Papua New Guinea, is exceptional because the lobsters disappear after they have finished spawning (Moore \& MacFarlane 1984). Juvenile $P$. ornatus in the Torres Strait emigrate northeastward each year, through the Gulf of Papua to the area around Yule Island, maturing as they travel. Fertilisation and spawning take place during the emigration and females may carry up to 3 broods in a season. The routes they take and the sequences of maturation and spawning have been studied in some detail (Moore \& MacFarlane 1984, MacFarlane \& Moore 1986, Prescott et al. 1986). However, once spawning is completed, the lobsters disappear from the Yule Island area. There is no evidence that the lobsters return to the Torres Strait or reappear at Yule Island in subsequent years. It has been suggested that the simultaneous physical and physiological demands of repro-

\footnotetext{
- Present address: Australian Independent Research, PO Box 7197. Cairns, Queensland 4870, Australia
}

duction and emigration might cause the death of most of the lobsters (MacFarlane \& Moore 1986).

The lobsters at Yule Island are often lethargic, appear to be in poor condition and to have wasted abdominal muscle. These features have not been quantified, but in a pilot cage experiment, lobsters from Yule Island had a much higher mortality rate than lobsters from the Torres Strait. These results support the hypothesis that large numbers at Yule Island die after spawning (MacFarlane \& Moore 1986).

The emigrating lobsters would be subjected to 2 principal sources of stress: (1) the energy requirements associated with walking long distances, possibly with limited opportunity for feeding, and (2) the physiological and behavioural demands of maturation, fertilisation and spawning.

In other Crustacea, physical and nutritional stress can result in catabolism of both digestive gland and muscle (Heath \& Barnes 1970, Dall 1974, 1975a, 1981, Barclay et al. 1983, Landau 1985, Whyte et al. 1986). In Panulirus cygnus, starvation was accompanied by an increase in the water content of the abdominal muscle and digestive gland and a reduction in muscle protein and digestive gland solids (Dall 1974). Starvation of 


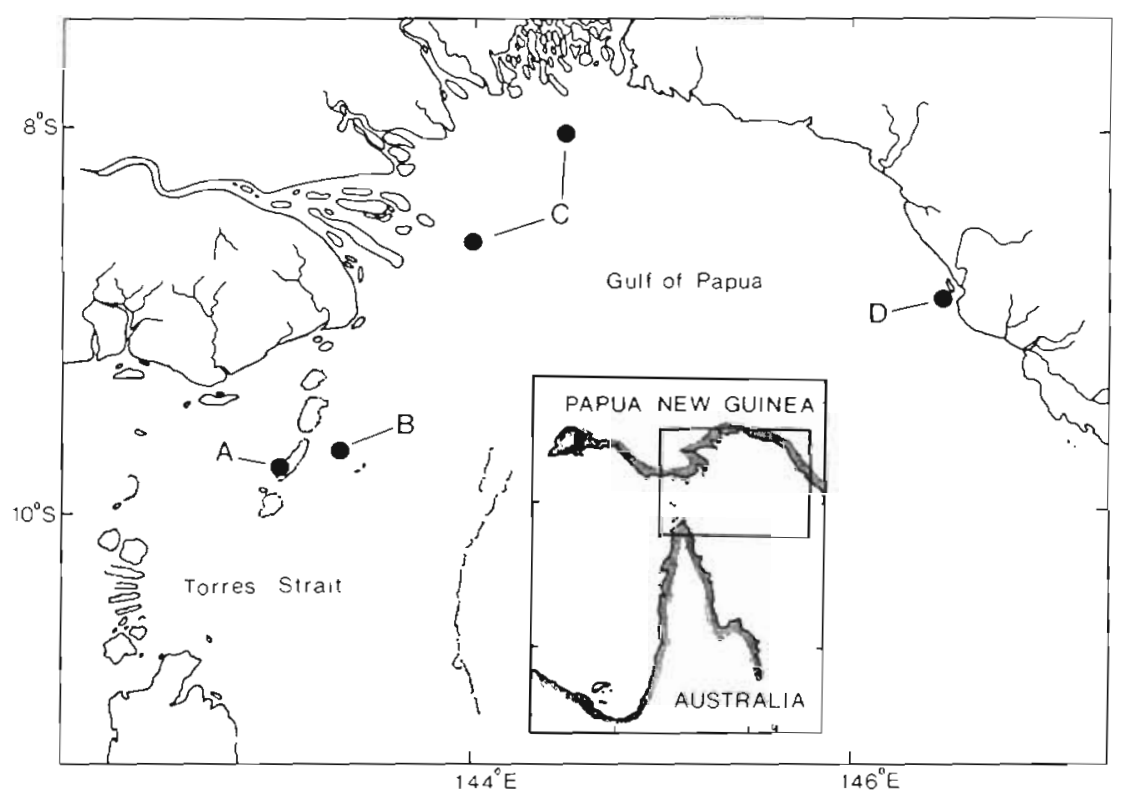

Fig. 1. Location of sampling sites in the Torres Strait and Gulf of Papua. (A) Torres Strait Reef, (B) Torres Strait trawl, (C) Gulf of Papua trawl, (D) Yule Island
Homarus americanus resulted in breakdown of digestive gland tissue (Stewart et al. 1967); more prolonged starvation of postlarval penaeus monodon caused irreversible damage to the digestive gland (Vogt et al. 1985). Any loss of condition in Panulirus ornatus that results from emigration and spawning should be evident in changes in the water content and composition of the digestive gland and abdominal muscle.

In this study, the water content and composition of the tissue are used to define the physiological condition of lobsters collected in the Torres Strait prior to emigration, in the Gulf of Papua during emigration and from Yule Island at the end of the emigration and after spawning. In addition a cage experiment, in which lobsters from Yule Island were held under 2 feeding regimes, was used to assess the likelihood of mortality at the end of the emigration.

\section{METHODS}

Sample collection. A total of 419 live lobsters were collected in 6 samples representing 3 major stages in the emigration. (1) Pre-emigration - divers using hand nets collected 33 lobsters from a reef in the Torres Strait (Fig. 1A) in February 1986, about 6 mo before emigration began. Another 71 lobsters were collected from a commercial prawn trawler in the Great Northeast Channel of the Torres Strait (Fig. 1B) in September 1985; most of these lobsters had recently started moving towards the Gulf of Papua. (2) Mid-emigration - in October and November 1985, 118 lobsters were collected from the catches of commercial prawn trawlers in the Gulf of Papua (Fig, 1C); these lobsters were probably about midway through the emigration. (3) Post-emigration - 3 samples of lobsters were collected at Yule Island (Fig. 1D) in 1986: an early-season sample in January-February; a mid-season sample in February-March; and a late-season sample at the end of March.

Cage experiment. A feeding experiment, using caged lobsters, was undertaken to determine whether lobsters from Yule Island could recover condition after the emigration or withstand further physiological stress. A total of 96 lobsters were collected at Yule Island in late February 1986, at the same time as the early-season sample, and held for $6 \mathrm{wk}$ until late March 1986. The experiment was ended immediately after the late-season sample had been collected.

In each of 2 feeding treatments there were 4 wire cages $(1 \times 3 \times 0.5 \mathrm{~m})$ with 6 male and 6 female lobsters in each cage. Lobsters in the High-food treatment were fed daily with fish, each cage receiving twelve $25 \mathrm{~g}$ pieces. The lobsters in the Low-food treatment were not fed but would have had very limited access to naturally ocurring foods. An additional cage in the Low-food treatment held 2 male and 3 female lobsters.

Sample storage and processing. All lobsters were collected alive, labelled, wrapped in plastic and stored for between 3 and 7 mo between -20 and $-30^{\circ} \mathrm{C}$ until processed in the laboratory. Most lobsters were processed between April and June 1986, with a final batch processed in November and December 1986.

Tissue analyses. There are several studies which have defined the relationship between stress and physical condition in decapod crustaceans (Stewart et al. 1967, Dall 1974, 1975b. Whyte et al. 1986). In this study, measures of physical condition were used to 
determine the degree of physiological stress experienced by the lobsters.

Sex, carapace length to $0.1 \mathrm{~mm}$ and total weight to $0.1 \mathrm{~g}$ (including eggs and tar-spots) were recorded for each lobster. As the lobsters often had missing antennae or legs when caught, all antennae, antennules and walking legs were removed from the frozen animals before weighing.

The frozen carcass was longitudinally bisected with a bandsaw and from one half 4 samples (about $2 \mathrm{~g}$ each) of the digestive gland and abdominal muscle were removed, weighed and freeze-dried to a constant weight. The water content of each tissue was calculated as the mean of the 4 samples. The precision of the samples was $\pm 0.60 \%$ for the abdominal muscle and $\pm 1.43 \%$ for the digestive gland. There was no evidence that freezing affected the water content of the tissue samples. Each whole lobster was wrapped in a plastic bag prior to freezing and this limited dehydration of internal tissues.

The rest of the digestive gland was dissected from both lobster halves, oven-dried for $48 \mathrm{~h}$ at $80^{\circ} \mathrm{C}$ and weighed. An approximate total dry weight of the digestive gland was calculated as the weight of the oven-dry tissue plus the weight of the 4 freeze-dried samples. From the half lobster with the intact muscle, the abdomen (with any eggs removed) was separated cleanly at the posterior edge of the carapace, weighed and ovendried. The bisected halves were $49.9 \pm 2.40 \%(n=50)$ of the total weight and the dry weight of muscle in the half lobster was used to estimate the proportion by weight of dry muscle tissue in the whole abdomen.

The freeze-dried tissue samples from the digestive gland and tail muscle were homogenised and analysed for the mass fractions of carbon and nitrogen in a Leco $600 \mathrm{CHN}$ analyser. Standard Bovine liver (carbon 47.75 \pm 0.36 , nitrogen $9.96 \pm 0.10$ ) and regular duplicate samples were used for instrument calibration and the precision of the determinations was better than $\pm 1 \%$ for carbon and $\pm 4 \%$ for nitrogen.

Ash weights of tail muscle and digestive gland tissue were obtained from 23 female and 9 male lobsters (from all samples except Yule Mid-season and Cage Low-food) by ashing samples of each tissue in a muffle furnace at $600^{\circ} \mathrm{C}$ for $24 \mathrm{~h}$. The original total carbon and nitrogen measurements were expressed as mass fractions of the ash-free dry weight according to the formula:

$W(e)=[$ Total $W(e)-\operatorname{ash} W(e)] \times W$ ash $/[1-W$ ash $]$,

where $W(e)=$ the corrected mass of the element $(e)$ in the sample; Total $W(e)=$ the total mass of the element (e) in the sample; ash $W(e)=$ the mass of the element (e) in the ash; and $W$ ash = the mass of ash in the tissue (Gnaiger \& Bitterlich 1984).
Data analysis. The difficulties of obtaining samples of lobsters from remote locations over 12 mo resulted in an unbalanced sampling design. For all measures of condition there was a significant interaction between sex and location which, in an unbalanced design, complicates post-hoc comparisons. To simplify comparisons between samples, the data from males and females were analysed separately

Apart from the $\mathrm{C}: \mathrm{N}$ ratio of the digestive gland, all analyses used transformed data. An arcsin transformation was applied to the measures expressed as percentages (water content, carbon content, nitrogen content, weight of abdominal muscle tissue) and a natural log transform was used for digestive gland dry weight. The dry weight of the digestive gland and the percentage weight of the abdominal muscle were correlated with carapace length at some locations; analysis of covariance was used to compare samples.

Comparisons between sexes were made with every sample location. The lobsters do not begin breeding until they reach the Gulf of Papua and the differences between the Pre-emigration samples taken in the Torres Strait and the Mid-emigration samples taken from the Gulf of Papua were small compared to the differences between the Pre-emigration samples and the Post-emigration samples from Yule Island. As a result, comparisons between locations were made by pooling the samples into 4 major categories: Pre-emigration (Torres Strait Reef, Torres Strait Trawl, Gulf of Papua); Post-emigration (Yule-Early, Yule-Mid, Yule-Late); High-food Cages; Low-food Cages.

\section{RESULTS}

\section{Size-weight relationships}

In the Torres Strait samples there was no difference in the carapace length (CL)/total weight relationship between males (In total weight $=2.896$ ln $\mathrm{CL}-$ 6.709 ) and females (ln total weight $=2.728$ ln CL 5.964) Analysis of covariance, $F(1,29)=0.557, p=$ 0.461). During the emigration, female lobsters appeared to gain weight: Torres Strait females were significantly lighter than females from the Early-season sample at Yule Island (Analysis of covariance $F$ $(7,297)=10.269, p<0.0001)$. However, the females were carrying external sperm packets and egg masses, both of which increased their total weight. Male lobsters lost weight (Analysis of covariance, $F$ $(7,198)=11.78, \mathrm{p}<0.0001)$. In general, the differences between samples in total weight were too small to be useful as a measure of overall changes in physiological condition. 


\section{Water content}

\section{Digestive gland}

In all lobsters the water content of the digestive gland increased during the emigration, from ca $60 \%$ in Pre-emigration samples to ca $80 \%$ in Post-emigration samples (Fig. 2a; Tables 1 to 4 ). In the early stages of the emigration (Torres Strait Trawl, Gulf of Papua) female lobsters had a significantly lower water content than males (Fig. 2a). However, at the end of the emigration this difference was reversed and the digestive gland of females from the Mid-season sample at Yule Island had a significantly higher water content than the males (Fig. 2a).

In both sexes the lobsters in the Low-food treatment were in the poorest condition; their digestive glands had the highest water contents. The lobsters in the

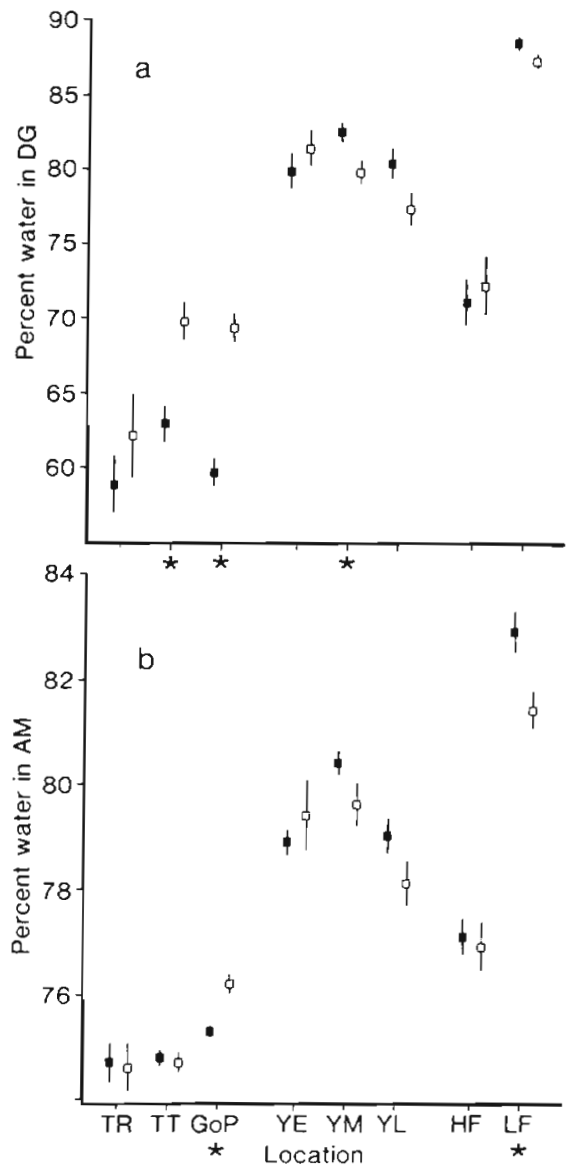

Fig. 2. Panulinus ornatus. Percentage water content of (a) digestive gland and (b) abdominal muscle of female ( $(\mathbf{c})$ and male ( 0 ) lobsters. Values are means and standard errors. TR: Torres Strait Reef; TT: Torres Strait Trawli GoP: Gulf of Papua; YE: Yule Island Early-season; YM: Yule Island Midseason; YL: Yule Island Late-season; HF: High-food Cages; LF: Low-food Cages. "Samples in which there was a significant difference between sexes $(p<0.05)$
High-food treatment were in significantly better condition at the end of $6 \mathrm{wk}$ than those sampled from the field at Yule Island (Tables 1 to 4 ).

\section{Abdominal muscle}

The water content of the muscle also increased in the course of the emigration, from ca $75 \%$ in the Preemigration samples to ca $79 \%$ in the Post-emigration samples (Tables 1 to 4 ; Fig. 2 b). As was the case with the digestive gland, the abdominal muscles of males were initially in poorer condition, with a significantly higher water content than those of females (e.g. Fig. 2b, Gulf of Papua). At the end of the Low-food treatment, females were in poorer condition than males (Fig. 2b). At the end of the study, the lobsters in the Low-food cages were in poorest condition, while those in the High-food treatment showed an improvement in condition (Tables 1 to 4 ).

\section{Tissue dry weight}

In both the digestive gland and abdominal muscle the increase in the water content of the tissue in the course of the emigration was accompanied by a change in tissue dry weight, which decreased from ca 11 to $12 \mathrm{~g}$ in the Pre-emigration samples to $\mathrm{ca} 5 \mathrm{~g}$ in the Postemigration Yule Island samples; these were still significantly larger than the 1 to $2 \mathrm{~g}$ tissue weights from lobsters at the end of the Low-food treatment (Tables 1 to 4). In both sexes the Post-emigration lobsters had significantly less muscle tissue in the abdomen than Pre-emigration lobsters (Tables 1 to 4 ), with the change being greatest in female lobsters (Tables 1 and 3 ).

\section{Tissue composition}

Digestive gland

The ash content of the digestive gland tended to increase as the dry weight of tissue decreased. The mass fractions of ash ( $\mathrm{W}$ ash) that were used to correct the total carbon and nitrogen measurements in each sample were: Torres Strait Reef, 0.04; Torres Strait Trawl and Gulf of Papua, 0.045; Yule Early-season and Late-season, 0.08; Yule Mid-season, 0.085; High-food treatment, 0.05; Low-food treatment, 0.1 . The values used for the elemental composition of the ash in the digestive gland were ash $W(C)=0.14$ and ash $W(N)=$ 0.045 (Gnaiger \& Bitterlich 1984, Whyte et al. 1986)

In the course of the emigration the carbon content of the digestive gland decreased and the nitrogen content 
Table 1. Panulirus ornatus. Tissue water content, weight and composition of the digestive gland and abdominal muscle of female lobsters from all locations. Means, standard errors and sample sizes are given. Samples with the same subscript are not significantly different $(p<0.05)$. See Table 3 for detailed comparisons

\begin{tabular}{|c|c|c|c|c|c|}
\hline \multirow[t]{2}{*}{ Measure } & \multirow[t]{2}{*}{ Parameter } & \multicolumn{2}{|c|}{ Digestive gland } & \multicolumn{2}{|c|}{ Abdominal muscle } \\
\hline & & $\mathrm{x} \pm \mathrm{SE}$ & $\mathrm{n}$ & $x \pm S E$ & $\mathrm{n}$ \\
\hline Percent water content & $\begin{array}{l}\text { Pre-emigration } \\
\text { High-food } \\
\text { Post-emigration } \\
\text { Low-food }\end{array}$ & $\begin{array}{l}60.4 \pm 0.66 \\
71.1 \pm 1.59 \\
81.3 \pm 0.53 \\
88.5 \pm 0.41\end{array}$ & $\begin{array}{r}(145) \\
(23) \\
(115) \\
(24)\end{array}$ & $\begin{array}{l}75.0 \pm 0.09 \\
77.1 \pm 0.35 \\
79.6 \pm 0.16 \\
82.9 \pm 0.40\end{array}$ & $\begin{array}{r}(145) \\
(23) \\
(115) \\
(24)\end{array}$ \\
\hline Tissue weight (see text) & $\begin{array}{l}\text { Pre-emigration } \\
\text { High-food } \\
\text { Post-emigration } \\
\text { Low-food }\end{array}$ & $\begin{array}{r}14.3 \pm 0.48 \\
6.9 \pm 1.18 \\
4.1 \pm 0.33 \\
1.2 \pm 0.19\end{array}$ & $\begin{array}{r}(42) \\
(12)_{a} \\
(46)_{a} \\
(7)_{a}\end{array}$ & $\begin{array}{r}18.6 \pm 0.25 \\
16.5 \pm 0.36 \\
13.6 \pm 0.27 \\
9.6 \pm 0.47\end{array}$ & $\begin{array}{r}(72) \\
(23) \\
(102) \\
(23)\end{array}$ \\
\hline Percent carbon & $\begin{array}{l}\text { Pre-emigration } \\
\text { High-food } \\
\text { Post-emigration } \\
\text { Low-food }\end{array}$ & $\begin{array}{l}64.4 \pm 0.44 \\
58.2 \pm 1.20 \\
49.5 \pm 0.59 \\
38.8 \pm 0.56\end{array}$ & $\begin{array}{r}(146) \\
(23) \\
(117) \\
(24)\end{array}$ & $\begin{array}{l}49.2 \pm 0.06 \\
48.0 \pm 0.30 \\
47.4 \pm 0.17 \\
43.9 \pm 1.00\end{array}$ & $\begin{array}{l}(92) \\
(11)_{b} \\
(45)_{b} \\
(7)\end{array}$ \\
\hline Percent nitrogen & $\begin{array}{l}\text { Pre-emigration } \\
\text { High-food } \\
\text { Post-emigration } \\
\text { Low-food }\end{array}$ & $\begin{array}{l}4.7 \pm 0.12 \\
6.4 \pm 0.35 \\
8.9 \pm 0.15 \\
9.8 \pm 0.13\end{array}$ & $\begin{array}{r}(146) \\
(23) \\
(117) \\
(24)\end{array}$ & $\begin{array}{l}15.8 \pm 0.02 \\
16.0 \pm 0.07 \\
15.9 \pm 0.04 \\
14.5 \pm 0.47\end{array}$ & $\begin{array}{l}(92)_{c} \\
(11)_{c} \\
(45)_{c} \\
(7)\end{array}$ \\
\hline$C: N$ ratio & $\begin{array}{l}\text { Pre-emigration } \\
\text { High-food } \\
\text { Post-emigration } \\
\text { Low-food }\end{array}$ & $\begin{array}{r}15.1 \pm 0.39 \\
9.9 \pm 0.81 \\
6.0 \pm 0.23 \\
4.0 \pm 0.07\end{array}$ & $\begin{array}{r}(146) \\
(23) \\
(117) \\
(24)\end{array}$ & & \\
\hline
\end{tabular}

Table 2. Panulirus ornatus. Tissue water content, weight and composition of the digestive gland and abdominal muscle of male lobsters from all locations. Means, standard errors and sample sizes are given. Samples with the same subscript are not significantly different $(p<0.05)$. See Table 4 for detailed comparisons

\begin{tabular}{|c|c|c|c|c|c|}
\hline \multirow[t]{2}{*}{ Measure } & \multirow[t]{2}{*}{ Parameter } & \multicolumn{2}{|c|}{ Digestive gland } & \multicolumn{2}{|c|}{ Abdominal muscle } \\
\hline & & $x \pm S E$ & $\mathrm{n}$ & $\mathrm{x} \pm \mathrm{SE}$ & $\mathrm{n}$ \\
\hline \multirow[t]{4}{*}{ Percent water content } & Pre-emigration & $68.2 \pm 0.86$ & $(87)$ & $75.4 \pm 0.16$ & $(87)$ \\
\hline & High-food & $72.2 \pm 1.99$ & (18) & $76.9 \pm 0.46$ & (18) \\
\hline & Post-emigration & $79.2 \pm 0.66$ & $(80)$ & $78.9 \pm 0.29$ & $(80)$ \\
\hline & Low-food & $87.3 \pm 0.53$ & $(21)$ & $81.4 \pm 0.35$ & (21) \\
\hline \multirow[t]{4}{*}{ Tissue weight (see text) } & Pre-emigration & $11.3 \pm 0.35$ & $(42)$ & $17.6 \pm 0.40$ & $(70)_{\mathrm{b}}$ \\
\hline & High-food & $5.6 \pm 0.72$ & $(7)_{\mathrm{d}}$ & $16.4 \pm 0.60$ & $(18)_{\mathrm{b}}$ \\
\hline & Post-emigration & $6.5 \pm 0.48$ & $(22)_{a}$ & $16.9 \pm 0.12$ & $(82)_{\mathrm{b}}$ \\
\hline & Low-food & $2.1 \pm 0.05$ & $(14)$ & $11.7 \pm 0.60$ & $(22)$ \\
\hline \multirow[t]{4}{*}{ Percent carbon } & Pre-emigration & $59.9 \pm 0.57$ & $(80)$ & $49.0 \pm 0.07$ & $(59)$ \\
\hline & High-food & $57.1 \pm 1.38$ & (19) & $47.8 \pm 0.25$ & $(9)_{c}$ \\
\hline & Post-emigration & $50.7 \pm 0.64$ & $(80)$ & $47.7 \pm 0.30$ & $(24)_{c}$ \\
\hline & Low-food & $41.7 \pm 0.50$ & $(21)$ & $46.3 \pm 0.21$ & $(13)_{c}$ \\
\hline \multirow[t]{4}{*}{ Percent nitrogen } & Pre-emigration & $6.0 \pm 0.16$ & $(88)_{\mathrm{d}}$ & $16.0 \pm 0.03$ & $(59)_{e}$ \\
\hline & High-food & $6.5 \pm 0.35$ & $(19)_{\mathrm{d}}$ & $15.7 \pm 0.11$ & $(9)_{e}$ \\
\hline & Post-emigration & $8.5 \pm 0.16$ & $(80)$ & $15.7 \pm 0.10$ & $(24)_{e}$ \\
\hline & Low-food & $10.5 \pm 0.13$ & (21) & $15.6 \pm 0.13$ & $(13)_{e}$ \\
\hline \multirow[t]{4}{*}{$C: N$ ratio } & Pre-emigration & $10.8 \pm 0.37$ & $(88)$ & & \\
\hline & High-food & $9.4 \pm 0.72$ & (19) & & \\
\hline & Post-emigration & $6.2 \pm 0.20$ & $(80)$ & & \\
\hline & Low-food & $4.0 \pm 0.07$ & (21) & & \\
\hline
\end{tabular}


Table 3. Panulirus ornatus. Analysis of variance tables for female lobsters for the comparisons between locations. All measures except the digestive gland $C: N$ ratio have been transformed

\begin{tabular}{|c|c|c|c|c|c|}
\hline Measure & Source & $\mathrm{df}$ & MS & $\mathrm{F}$ & $\mathrm{p}$ \\
\hline \multicolumn{6}{|l|}{ Digestive gland } \\
\hline Water content & $\begin{array}{l}\text { Location } \\
\text { Residual }\end{array}$ & $\begin{array}{r}3 \\
303\end{array}$ & $\begin{array}{c}1.564 \\
5.65 \times 10^{-3}\end{array}$ & 276.56 & $<0.0001$ \\
\hline Tissue weight & $\begin{array}{l}\text { Location } \\
\text { CL } \\
\text { Residual }\end{array}$ & $\begin{array}{r}3 \\
1 \\
102\end{array}$ & $\begin{array}{r}16.225 \\
13.974 \\
0.209\end{array}$ & $\begin{array}{l}77.65 \\
66.88\end{array}$ & $\begin{array}{l}<0.0001 \\
<0.0001\end{array}$ \\
\hline \multicolumn{6}{|c|}{ (no significant difference in slopes) } \\
\hline Percent carbon & $\begin{array}{l}\text { Location } \\
\text { Residual }\end{array}$ & $\begin{array}{r}3 \\
306\end{array}$ & $\begin{array}{c}0.773 \\
3.32 \times 10^{-3}\end{array}$ & 233.12 & $<0.0001$ \\
\hline Percent nitrogen & $\begin{array}{l}\text { Location } \\
\text { Residual }\end{array}$ & $\begin{array}{r}3 \\
306\end{array}$ & $\begin{array}{c}0.191 \\
9.72 \times 10^{-4}\end{array}$ & 196.03 & $<0.0001$ \\
\hline$C: N$ ratio & $\begin{array}{l}\text { Location } \\
\text { Residual }\end{array}$ & $\begin{array}{r}3 \\
306\end{array}$ & $\begin{array}{l}2174.98 \\
13.99\end{array}$ & 155.44 & $<0.0001$ \\
\hline \multicolumn{6}{|c|}{ Abdominal muscle } \\
\hline Water content & $\begin{array}{l}\text { Location } \\
\text { Residual }\end{array}$ & $\begin{array}{r}3 \\
303\end{array}$ & $\begin{array}{c}0.104 \\
3.16 \times 10^{-4}\end{array}$ & 329.33 & $<0.0001$ \\
\hline Tissue weight & $\begin{array}{l}\text { Location } \\
\text { Residual }\end{array}$ & $\begin{array}{r}3 \\
216\end{array}$ & $\begin{array}{c}0.128 \\
1.19 \times 10^{-3}\end{array}$ & 107.58 & $<0.0001$ \\
\hline Percent carbon & $\begin{array}{l}\text { Location } \\
\text { Residual }\end{array}$ & $\begin{array}{r}3 \\
151\end{array}$ & $\begin{array}{l}8.19 \times 10^{-3} \\
9.30 \times 10^{-5}\end{array}$ & 87.87 & $<0.0001$ \\
\hline Percent nitrogen & $\begin{array}{l}\text { Location } \\
\text { Residua] }\end{array}$ & $\begin{array}{r}3 \\
151\end{array}$ & $\begin{array}{l}8.21 \times 10^{-4} \\
2.30 \times 10^{-5}\end{array}$ & 34.99 & $<0.0001$ \\
\hline
\end{tabular}

Table 4. Panulirus ornatus. Analysis of variance tables for male lobsters for the comparisons between locations. All measures except the digestive gland $\mathrm{C}: \mathrm{N}$ ratio have been transformed

\begin{tabular}{|c|c|c|c|c|c|}
\hline Measure & Source & $\mathrm{df}$ & MS & $\mathrm{F}$ & $\mathrm{p}$ \\
\hline \multicolumn{6}{|l|}{ Digestive gland } \\
\hline Water content & $\begin{array}{l}\text { Location } \\
\text { Residual }\end{array}$ & $\begin{array}{r}3 \\
202\end{array}$ & $\begin{array}{c}0.415 \\
6.09 \times 10^{-3}\end{array}$ & 68.17 & $<0.0001$ \\
\hline Tissue weight & $\begin{array}{l}\text { Location } \\
\text { CL } \\
\text { Residual }\end{array}$ & $\begin{array}{r}3 \\
1 \\
80\end{array}$ & $\begin{array}{r}10.243 \\
16.439 \\
0.236\end{array}$ & $\begin{array}{l}43.30 \\
69.48\end{array}$ & $\begin{array}{l}<0.001 \\
<0.0001\end{array}$ \\
\hline \multicolumn{6}{|c|}{ (significant difference between slopes) } \\
\hline Percent carbon & $\begin{array}{l}\text { Location } \\
\text { Residual }\end{array}$ & $\begin{array}{r}3 \\
204\end{array}$ & $\begin{array}{c}0.246 \\
2.95 \times 10^{-3}\end{array}$ & 83.30 & $<0.0001$ \\
\hline Percent nitrogen & $\begin{array}{l}\text { Location } \\
\text { Residual }\end{array}$ & $\begin{array}{r}3 \\
204\end{array}$ & $\begin{array}{l}5.97 \times 10^{-2} \\
7.46 \times 10^{-4}\end{array}$ & 80.04 & $<0.0001$ \\
\hline$C: N$ ratio & $\begin{array}{l}\text { Location } \\
\text { Residual }\end{array}$ & $\begin{array}{r}3 \\
204\end{array}$ & $\begin{array}{r}435.78 \\
7.32\end{array}$ & 59.51 & $<0.0001$ \\
\hline \multicolumn{6}{|c|}{ Abdominal muscle } \\
\hline Water content & $\begin{array}{l}\text { Location } \\
\text { Residual }\end{array}$ & $\begin{array}{r}3 \\
202\end{array}$ & $\begin{array}{c}0.044 \\
6.26 \times 10^{-4}\end{array}$ & 69.61 & $<0.0001$ \\
\hline Tissue weight & $\begin{array}{l}\text { Location } \\
\text { CL } \\
\text { Residual }\end{array}$ & $\begin{array}{r}3 \\
1 \\
187\end{array}$ & $\begin{array}{c}0.038 \\
0.010 \\
2.18 \times 10^{-3}\end{array}$ & $\begin{array}{r}17.50 \\
4.84\end{array}$ & $\begin{array}{c}<0.0001 \\
0.029\end{array}$ \\
\hline \multicolumn{6}{|c|}{ (significant difference between slopes) } \\
\hline Percent carbon & $\begin{array}{l}\text { Location } \\
\text { Residual }\end{array}$ & $\begin{array}{r}3 \\
101\end{array}$ & $\begin{array}{l}2.86 \times 10^{-3} \\
7.80 \times 10^{-5}\end{array}$ & 36.60 & $<0.0001$ \\
\hline Percent nitrogen & $\begin{array}{l}\text { Location } \\
\text { Residual }\end{array}$ & $\begin{array}{r}3 \\
101\end{array}$ & $\begin{array}{l}1.44 \times 10^{-4} \\
2.50 \times 10^{-5}\end{array}$ & 5.88 & $<0.001$ \\
\hline
\end{tabular}




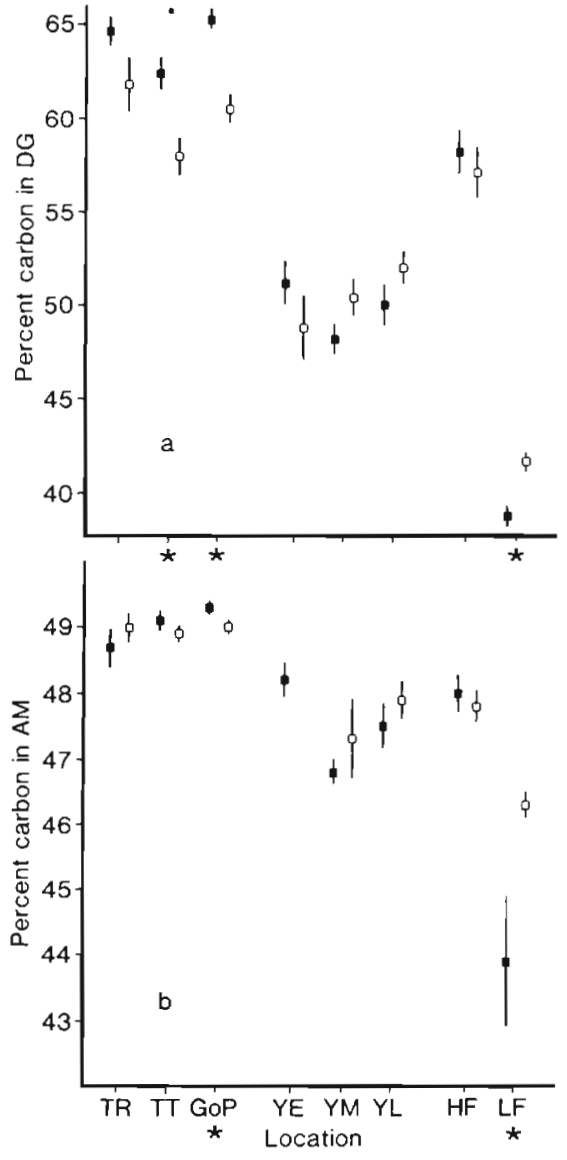

Fig. 3. Panulirus ornatus. Percentage carbon in (a) digestive gland and (b) abdominal muscle of female ( $\mathbf{a}$ ) and male (a) lobsters. Values are means and standard errors. Location codes as for Fig. 2

increased (Tables 1 to 4 ). As was observed for the water content of the tissue, females started the emigration in better condition than males, but finished in poorer condition (Figs. $3 \mathrm{a}$ and 4 a).

In both sexes the overall pattern was the same: lobsters at the completion of the Low-food treatment were in poorest condition, with the lowest levels of carbon and highest levels of nitrogen. Although the condition of the lobsters in the High-food cages became significantly better than that of the Yule Island lobsters, with more carbon and less nitrogen in the digestive gland, they were still in poorer condition than lobsters from the Pre-emigration samples (Tables 1 to 4 ).

In general the changes in nitrogen content mirrored those of carbon (Fig. 4a). An important exception to this pattern, which is examined in detail in the 'Discussion', is that females in the Low-food treatment had significantly lower levels of nitrogen than males (Fig, 4a).

During the emigration, as the percentage of carbon in the digestive gland decreased and the percentage of

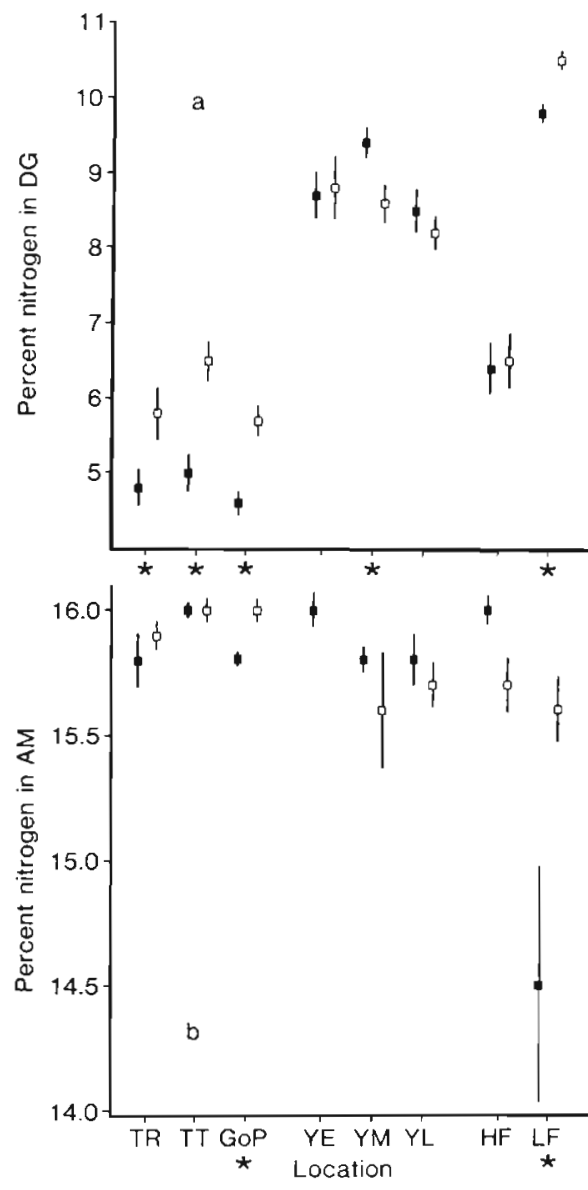

Fig. 4. Panulirus ornatus. Percentage nitrogen in (a) digestive gland and (b) abdominal muscle of female (a) and male ( $\square$ ) lobsters. Values are means and standard errors. Location codes as for Fig. 2

nitrogen increased, the $\mathrm{C}: \mathrm{N}$ ratio decreased by about half (Fig. 5). The lobsters in the Low-food treatment had the lowest $\mathrm{C}: \mathrm{N}$ values (Tables 1 to 4 ).

\section{Abdominal muscle}

The ash content of abdominal muscle tissue did not vary between samples $(F(5,25)=1.357, p=0.274)$. A mass fraction of $\mathrm{W}$ ash $=0.074$ was used to adjust the total carbon and nitrogen values for lobsters from all samples except the Low-food cage treatment, for which a conservative correction of $W$ ash $=0.09$ was used. Values for the elemental composition of muscle tissue ash were ash $\mathrm{W}(\mathrm{C})=0.002$ and ash $\mathrm{W}(\mathrm{N})=0.004$ (Gnaiger \& Bitterlich 1984, Whyte et al. 1986).

Only lobsters processed between April and June 1986 were included in the analyses of abdominal muscle composition because they had consistently higher levels of nitrogen than tissues processed in November and December 1986. This finding conflicts with other 


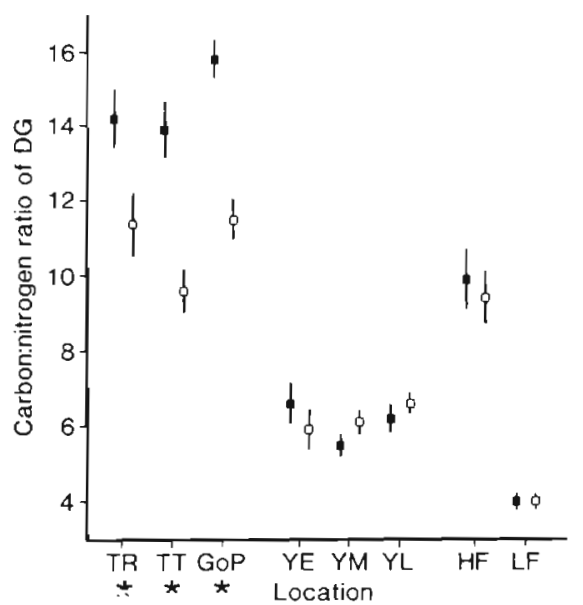

Fig. 5. Panulirus ornatus. C:N ratio of the digestive gland for female ( $)$ and male (c) lobsters. Values are means and standard errors. Location codes as for Fig. 2

studies (Wessels 1975), which have noted little change in lobster tissue held at $-30^{\circ} \mathrm{C}$ for several months. Few of the differences were significant, but they increased the variation within samples and confounded detection of differences between samples.

The carbon content of the abdominal muscle decreased during the emigration, most obviously in female lobsters, which were in better condition than males early in the emigration (e.g. Gulf of Papua; Tables 1 to 4).

With one important exception, there was very little difference between samples in the nitrogen content of the muscle (Tables 1 to 4 ; Fig. $4 \mathrm{~b}$ ). The females in the Low-food treatment had significantly less nitrogen in the abdominal muscle than those in all other samples (Tables 1 to 4 ; Fig. 4b).

\section{Cage experiment}

During the $6 \mathrm{wk}$ of the experiment, some lobsters died in both treatments. Of 48 lobsters in the High-food treatment there were 6 deaths ( 2 while moulting) and 12 moults (10 survivors). In the Low-food treatment there were 53 lobsters, of which 8 died $(5$ while moulting) and 6 moulted (1 survived). There was no significant difference between treatments in the proportion of lobsters that moulted $\left(\mathrm{G}_{1}=2.332, \mathrm{p}>0.05\right)$, but in the Low-food treatment significantly more lobsters that moulted died (Fisher's Exact. Test, $p=0.0124$ ).

\section{DISCUSSION}

In all of the measures of water content, weight and composition of tissue the Post-emigration lobsters at Yule Island were in significantly poorer condition than any of the lobsters in the Pre-emigration samples (Tables 1 to 4). This loss of condition reflects the physiological costs of the emigration. Virtually all ovarian maturation and spawning take place after the onset of the breeding emigration (MacFarlane \& Moore 1986) and because female lobsters produce as many as 3 batches of eggs they probably incur a greater physiological cost than males. This is consistent with the marked loss of condition of females, which started in better condition than males but finished in poorer condition. Females in the Pre-emigration samples had significantly less water in the digestive gland (Fig. 2a) as well as a higher $C: N$ ratio (Fig. 5), indicating greater lipid and carbohydrate reserves. However, in the Postemigration samples, female lobsters were in poorer condition than males (Figs. $2 \mathrm{a}$ and $4 \mathrm{a}$ ).

The loss of condition of the lobsters during emigration involves catabolism of both digestive gland and abdominal muscle tissues. In decapod Crustacea, lipids and proteins are considered to be the major energy reserves. However, their relative importance and the sequence of utilisation may vary among species, as can the relative importance of the digestive gland and muscle tissue as storage organs (Armitage et al. 1972, Barclay et al. 1983, Whyte et al. 1986). In Panulirus longipes energy is drawn from lipids in the digestive gland and proteins in the muscle, with the proteins being the most important source of energy (Dall 1974). The situation with $P$. ornatus is probably similar. The change in water content and composition of the digestive gland was more marked than in the abdominal muscle. Of the 2 tissues, the digestive gland is the most sensitive indicator of physiological stress, while the abdominal muscle is the most important energy reserve. For example, in the course of the emigration a female lobster of $100 \mathrm{~mm}$ carapace length is estimated to have used about $7 \mathrm{~g}$ of lipid from the digestive gland and $20 \mathrm{~g}$ of protein from the tail muscle to derive $270 \mathrm{~kJ}$ and $344 \mathrm{~kJ}$ respectively. Although these are rough estimates, they suggest that the tissue reserves only provide a small proportion of the total energy requirement during the emigration. Assuming a metabolic rate of $0.1 \mathrm{ml} \mathrm{O}_{2} \mathrm{~g}^{-1}$ wet $\mathrm{wth}^{-1}$ at the ambient water temperature, a $100 \mathrm{~mm} \mathrm{CL}$ lobster walking for $100 \mathrm{~d}$ would consume $181.4 \mathrm{l}$ of oxygen and metabolise $191 \mathrm{~g}$ of protein or $91 \mathrm{~g}$ of lipid. This suggests that they must feed during the emigration.

However, it appears that feeding is not an adequate source of energy for the lobsters, as substantial atrophy of the digestive gland and abdominal muscle occurs during the emigration. The sequence in which the reserves from the digestive gland and muscle are utilised is important and, by pooling the data from all samples 3 stages in a continuum of change can be recognised. 
Initially, the lobsters draw mainly on the energy reserves in the digestive gland, as shown by the increase in the water content from ca $50 \%$ (by weight) to ca $75 \%$ (Fig. 6,a). At this time, the water content of the abdominal muscle also increases, indicating utilisation of energy reserves, but to a lesser extent (Fig. 6,a).

In the second stage, which begins after the digestive gland has reached a water content of ca $75 \%$, the lobsters draw more heavily on the abdominal muscle (Fig. 6,b), whose water content increases more rapidly as the energy reserves in the muscle are utilised. The water content of these tissues is a good indicator of the first 2 stages in the loss of condition of the lobsters

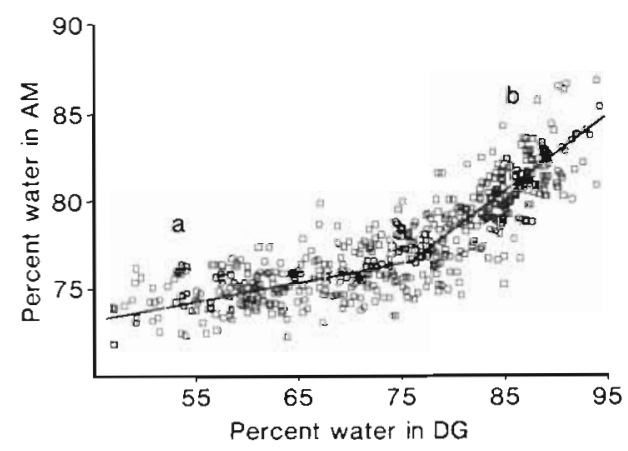

Fig. 6. Panulirus omatus. Percentage water content of abdominal muscle versus digestive gland for female lobsters from field and cage samples. Regression lines are: $\mathrm{a}-\mathrm{Y}=0.099 \mathrm{X}+$ $69.091, \mathrm{p}<0.001 ; \mathrm{b}-\mathrm{Y}=0.417 \mathrm{X}+45.265, \mathrm{p}<0.001$ Breakpoint is $74.8 \%$

The third stage in loss of condition was best observed in the composition of the digestive gland tissue. The $C: N$ ratio of the digestive gland reflects the relative proportions of lipid-carbohydrate and protein (Gnaiger $\&$ Bitterlich 1984). Tissue proteins are the principal source of nitrogen in the digestive gland. As the lipid and carbohydrate (carbon) reserves are reduced, the proportion of tissue protein, and hence nitrogen, in the gland increases and the $C: N$ ratio decreases. The $C: N$ ratio reaches a minimum when the energy reserves of the digestive gland have been completely exhausted and the carbon and nitrogen in tissue protein are the principal remaining constituents. Any further utilisation of digestive gland tissue will decrease tissue proteins, using carbon and nitrogen at the same rate so that the $C: N$ ratio remains constant. A plot, for female lobsters, of $C: N$ ratio against the water content of the digestive gland indicates that the $C: N$ ratio reaches this minimum value at a water content of ca $85 \%$ (Fig. 7).

At this point the water content of the tissue continues to increase while the $C: N$ ratio remains constant (Fig. 7 ). In other words, catabolism of digestive gland tissue continues, despite exhaustion of lipid and carbohydrate reserves. This third stage in the loss of condition can be

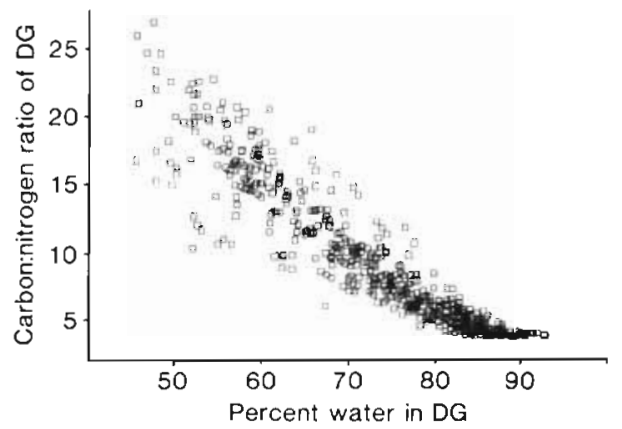

Fig. 7. Panulirus ornatus. C: $\mathrm{N}$ ratio versus percentage water of the digestive gland for female lobsters from field and cage samples

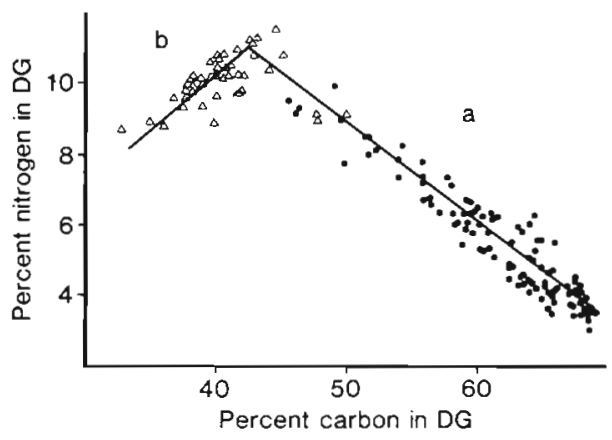

Fig. 8. Panulirus ornatus. Percentage nitrogen versus carbon in the digestive gland of female lobsters from the Pre-emigration samples ( $\bullet$ ) and all lobsters from the Low-food cages $(\Delta)$. Regression lines are: $\mathrm{a}-\mathrm{Y}=0.744+0.238 \mathrm{X}, \mathrm{p}<0.001 ; \mathrm{b}-\mathrm{Y}$ $=21.207-0.258 \mathrm{X}, \mathrm{p}<0.001$

seen most clearly in a comparison of the relative changes of carbon and nitrogen in the digestive gland. As the lobsters lose condition during the emigration the percentage of carbon in the digestive gland decreases while the percentage of nitrogen increases. This is indicated as line (a), the Torres Strait samples, in Fig. 8. The critical stage is reached when the digestive gland has a carbon content of about $41 \%$ by weight, corresponding to a $\mathrm{C}: \mathrm{N}$ ratio of about 3.9 (the minimum observed $C: N$ ratio was 3.72 and the mode of all $C: N$ values less than 5.0 was 3.87 ). After this point, carbon and nitrogen both decrease at the same rate, as was evident in the lobsters from the Low-food treatment (Fig. 8,b). At a C:N ratio of 3.9, when the lobsters have exhausted the lipid and carbohydrate reserves of the digestive gland, the rate at which abdominal muscle tissue is utilised increases dramatically (Fig. 9).

There are 2 areas in which we can look for evidence to support or refute the hypothesis that mass mortalities occur in the Yule Island population: (1) the time sequence of samples from the beginning through to the end of the Yule Island season, and (2) the response of the Yule Island lobsters to the experimental feeding treatments. 

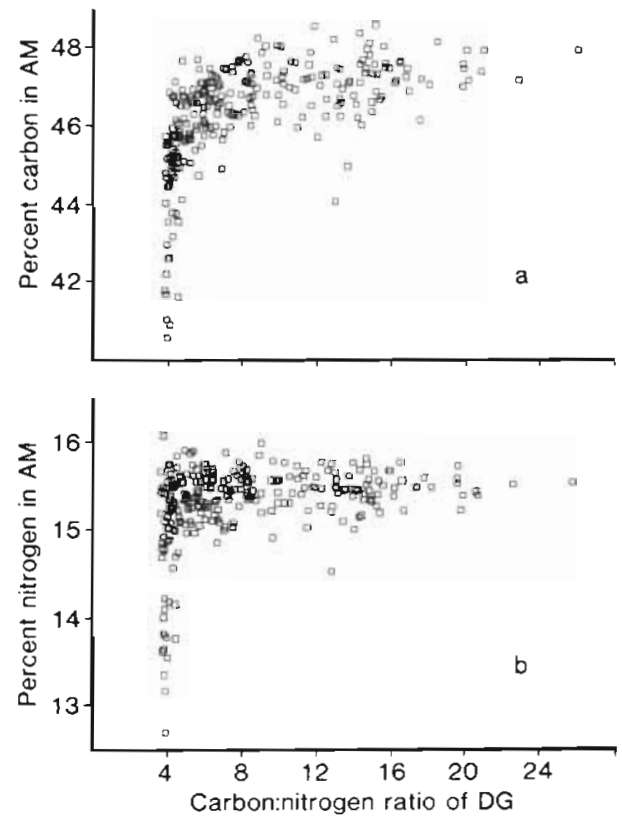

Fig. 9. Panulirus ornatus. Percentage (a) carbon and (b) nitrogen in the abdominal muscle versus the $\mathrm{C}: \mathrm{N}$ ratio of the digestive gland for female lobsters from field and cage samples

The lobsters start to arrive at Yule Island in December. Breeding continues through most of February, with females bearing at least 2 and often 3 consecutive broods (MacFarlane \& Moore 1986). Because breeding and its associated expenditure of energy continue at Yule Island, we might expect samples taken through the Yule Island season to show a steady decline in the condition of the population. This was not the case and, in the digestive gland in particular, different patterns were observed in males and females. In general, condition of male lobsters improved through the Yule Island season, while that of the females deteriorated. A loss of condition of females towards the middle of the season would be expected, given the extra effort of bearing successive broods. However, the improvement in the condition of the males is unexpected and suggests recovery.

It is impossible to say whether the changes observed in the males at Yule Island represent recovery of the population or whether they are an artifact of the sampling method. Lobsters in very poor condition or close to death will suffer high mortalities and are unlikely to be caught in the field, with the result that each sample was probably drawn from the best lobsters in the Yule Island population at that time. A perceived improvement of the best lobsters through time may give a misleading view of the condition of the rest of the population

Regardless of whether the condition of the males sampled at Yule Island was typical of the population, the rate of improvement of lobsters in the field was only a fraction of that observed in lobsters in the High-food treatment (Fig. 5). The caged individuals were of course protected from predators and supplied with daily food. The response of the lobsters in the Low-food treatment indicated that the females at Yule Island were more susceptible than males to additional stress and it confirms that the female lobsters in the field were closer than males to the third, critical stage in the loss of condition (Figs. 3 b and 4 b). The rapidity with which the condition of females in the Low-food treatment deteriorated, relative to that of males, indicates that the condition of lobsters in the field could drop quickly once the digestive gland has reached a $C: N$ ratio of 3.9 .

When a lobster reaches Stage 3, its ability to digest food, forage effectively and avoid predators may well be impaired to the extent that it is unable to cope with the concurrent rapid deterioration in condition. This is potentially a 'point of no return', beyond which a lobster is physically unable to recover from the loss of condition. There is evidence from other studies of irreversible critical points, beyond which recovery is no longer possible. In Panulirus longipes the duration of nutritional stress determined the recovery time in Dall's (1975b) study, and some severely stressed lobsters failed to recover on re-feeding. Studies of post-larval (Vogt et al. 1985) and adult prawns (Whyte et al. 1986) have also found evidence of irreversible damage to the digestive gland and a 'point of no return' after prolonged periods of starvation.

A second type of mortality that might occur at Yule Island is less direct. Attrition of the digestive gland could result in impairment of its functions, which would prevent the lobsters from moulting successfully. The digestive gland plays a primary role in moulting and oogenesis in Nephrops (Dall 1981), and in Panulirus argus it has been shown to be important for both chitin synthesis and calcium storage during moulting (Tsokos et al. 1983). Homarus americanus has specific dietary requirements prior to moulting (Leavitt et al. 1979). If these requirements are not met, moulting may be delayed (Castell \& Budson 1974, Castell \& Covey 1976) but can still take place, even though the lobster is physiologically incapable of moulting and subsequently dies (Bayer et al. 1978). In prawns, physical recovery after stress can stimulate moulting before the digestive gland is physiologically competent. Whyte et al. (1986) found in feeding studies with Pandalus platyceros that moulting was suppressed during long periods of starvation but resumed immediately on refeeding. Many of these animals were not ready to moult and $55 \%$ of all mortalities in their study occurred during or immediately after moulting.

Possibly the stress of reproducing and emigrating 
inhibits moulting in Panulirus ornatus, so that lobsters at the end of the season at Yule Island are approaching the end of an inter-moult period. The recovery of lobsters in the field at Yule Island may be so slow that they moult before they are physiologically competent. This would be supported by the significantly higher incidence of moult-related mortalities in the Low-food treatment than the High-food treatment.

This study has defined the sequential loss of condition in lobsters that take part in the breeding emigration, and has identified several key characteristics that can be used to determine the relative condition of individual lobsters. It has established that the lobsters from Yule Island that have completed the emigration are severely stressed and their condition is such that some mortality is likely. However, it is not possible to say how much, if any, additional mortalities in the population might result from the stress of the emigration.

Acknowledgements. Invaluable assistance in the field was given by Stewart Bell and Joe Aitsi. Tim Skewes and Chey Rayner are thanked for helping dissect and process the laboratory samples. Alan Knott, Cassie Payne and the Laboratory Services Unit at the Australian Institute of Marine Science carried out the CHN analyses. Bruce Phillips provided advice and encouragement throughout, and Bill Dall, Derek Staples and Chris Crossland substantially improved early drafts of the manuscript. This work was funded in Australia by the Commonwealth Department of Primary Industry and Energy, Torres Strait Research Fund and was conducted jointly by the CSIRO Division of Fisheries, Tropical Rock Lobster Project (Australia) and the Department of Fisheries and Marine Resources (Papua New Guinea).

\section{LITERATURE CITED}

Armitage, K. B., Bukema, A. L., Willems, N. J. (1972). Organic constituents in the annual cycle of the crayfish Orconectes nais (Faxon). Comp. Biochem. Physiol. 41A: 825-842

Barclay, M. C., Dall, W., Smith, D. M. (1983). Changes in lipid and protein during starvation and the moulting cycle in the tiger prawn, Penaeus esculentus Haswell. J. exp. mar. Biol. Ecol. 68: 229-244

Bayer, R. C., Gallagher, M. L., Leavitt, D. F. (1978). Nutrient requirement of the lobster and nutrition pathology. Mar. Fish. Rev. 40: 44

Castell, J. D., Budson, S. D. (1974). Lobster nutrition: the effect on Homarus americanus of dietary protein levels. J. Fish. Res. Bd Can. 31: 1363-1370

Castell, J. D., Covey, J. F. (1976). Dietary lipid requirements of

This article was presented by Dr D. F. Alderdice, Nanaimo, British Columbia, Canada adult lobsters, Homarus americanus (M. E.). J. Nutr 106: $1159-1165$

Dall, W. (1974). Indices of nutritional state in the western rock lobster, Panulirus longipes (Milne Edwards). I. Blood and tissue constituents and water content. J. exp. mar Biol Ecol. 16: 167-180

Dall, W. (1975a). Blood carbohydrates in the western rock lobster Panulirus longipes (Milne Edwards). J. exp. mar. Biol. Ecol. 18: 227-238

Dall, W. (1975b). Indices of nutritional state in the western rock lobster, Panulirus longipes (Milne Edwards). II. Gastric fluid constituents. J. exp. mar Biol. Ecol. 18: 1-18

Dall, W. (1981). Lipid absorption and utilization in the Norwegian lobster, Nephrops norvegicus (L.). J. exp. Mar. Biol. Ecol. 50: 33-45

Gnaiger, E., Bitterlich, G. (1984). Proximate biochemical composition and caloric content calculated from elemental CHN analysis: a stoichiometric concept. Oecologia (Berl.) 62: $289-298$

Heath, J. R, Barnes, H. (1970). Some changes in biochemical composition with season and during the moulting cycle of the common shore crab, Carcinus maenas (L.). J. exp. mar Biol. Ecol. 5: 199-233

Landau, M. (1985). The nutritional chemistry of large and small shrimp (Penaeus stylirostris Stimpson) reared in an aquaculture/waste water system. Comp. Biochem. Physiol. 80A: 205-207

Leavitt, D. F., Bayer, R. C., Gallagher, M. L., Rittenburg, J. H. (1979). Dietary intake and nutritional characteristics in wild American lobsters (Homarus americanus). J. Fish. Res. Bd Can. 36: 965-969

MacFarlane, J. W., Moore, R. (1986). Reproduction of the ornate rock lobster, Panulirus ornatus (Fabricius), in Papua New Guinea. Aust. J. mar Freshwat Res. 37. 55-65

Moore, R., MacFarlane, J. W. (1984). Migration of the ornate rock lobster, Panulirus ornatus (Fabricius), in Papua New Guinea. Aust. J. mar. Freshwat. Res. 35: 197-212

Prescott, J., Phillips, B. F., Bell, R. S. (1986). Rock lobster research in Torres Strait. Aust. Fish. 45 (1): 2-4

Stewart, J. E., Cornick, J. W., Foley, D. M., Li, M. F., Bishop, C. M. (1967). Muscle weight relationship to serum proteins, hemocytes, and hepatopancreas in the lobster, Homarus americanus. J. Fish. Res. Bd Can. 24: 2339-2354

Tsokos, J., Kreisberg, R., Michaels, A., Komm, B., Linton, J. (1983). Respiratory and calcium transport properties of spiny lobster hepatopancreas mitochondria. Archs Biochem. Biophys. 224: 707-717

Vogt, G., Storch, V., Quinitio, E. T., Pascual, F. P. (1985). Midgut gland as monitor organ for the nutritional value of diets in Penaeus monodon (Decapoda). Aquaculture 48: 1-12

Wessells, J. P. H. (1975). The effect of storage temperature on the carapace content of frozen rock lobster Rep. Fish. Indust. Res. Inst., Univ. Cape Town 27.11-12

Whyte, J. N. C., Englar, J. R., Carswell, B. L., Medic, K. E. (1986). Influence of starvation and subsequent feeding on body composition and energy reserves in the prawn, Pandalus platyceros. Can. J. Fish. Aquat. Sci. 43: 1142-1148

Manuscript first received: March 24, 1989

Revised version accepted: July 25, 1989 